Original Research Article

\title{
Evaluation of antidepressant effect of aqueous extract of Psidium guajava leaves on Wistar albino rats
}

\author{
Chaitra S. R. ${ }^{1}$, Roopa P. Nayak ${ }^{2 *}$, Uttara Krishna ${ }^{1}$
}

${ }^{1}$ Post Graduate Student, ${ }^{2} \mathrm{HOD}$ Department of Pharmacology, Yenepoya Medical College, Yenepoya (Deemed to be University), Mangalore, Karnataka, India

Received: 04 December 2018 Accepted: 29 December 2018

\section{*Correspondence to: \\ Dr. Roopa P. Nayak, \\ Email: roopapnayak@ yenepoya.edu.in}

Copyright: (C) the author(s), publisher and licensee Medip Academy. This is an openaccess article distributed under the terms of the Creative Commons Attribution NonCommercial License, which permits unrestricted noncommercial use, distribution, and reproduction in any medium, provided the original work is properly cited.

\begin{abstract}
Background: Depression is one of the common mental disorder prevalent worldwide. Use of herbal medicines in the treatment of depression is becoming popular because of adverse effects of existing non herbal drugs. In this study Psidium guajava leaf aqueous extract is screened for antidepressant activity in Wistar albino rats.

Methods: Wistar albino rats of both sex were used. After performing acute toxicity study, dose of test drug was fixed to $100 \mathrm{mg} / \mathrm{kg}$ and $200 \mathrm{mg} / \mathrm{kg}$. Test and standard drugs were administered for 10 days orally. Standard drug used was Imipramine. Antidepressant activity was assessed using forced swim test and tail suspension test.

Results: Statistical analysis was done by one way ANOVA followed by Tukey Kramer. Aqueous extract of Psidium guajava leaves showed significant antidepressant activity. Both Psidium guajava aqueous extract (PGAE)$100 \mathrm{mg} / \mathrm{kg}$ and $200 \mathrm{mg} / \mathrm{kg}$ showed antidepressant effect but compared to $100 \mathrm{mg} / \mathrm{kg}$ dose of PGAE, $200 \mathrm{mg} / \mathrm{kg}$ showed significant antidepressant activity. Conclusions: From this study it can be concluded that aqueous extract of Psidium guajava leaves has antidepressant activity.
\end{abstract}

Keywords: Aqueous extract, Antidepressant, Psidium guajava leaf, Wistar Albino rats

\section{INTRODUCTION}

Psidium guajava is commonly known as guava, is a plant which is grown in tropical and subtropical regions. It is a small tree approximately $10-15 \mathrm{~m}$ in height. Leaves are oval in shape measuring $5-10 \mathrm{~cm}$ in length. The fruit of this plant is edible and also used in folk medicine. It is used in ethnomedicine as an antimalarial. Infusions of the leaves are used for treating fevers, for diarrhoea and as a tonic in psychiatry. ${ }^{1,2}$ The hydro-alcoholic extract of $P$. guajava was shown to decrease motor activity in mice. The leaves of $P$. guajava contain an essential oil rich in cineol, tannins and triterpenes. In addition, three flavonoids have been isolated from the leaves. Methanolic extract of guava leaves has got anti-inflammatory and analgesic activity. ${ }^{3,4}$ Leaf extract has also been used as remedy for diabetes mellitus. Plant products are used as home remedies for minor ailments. ${ }^{5,6}$ If research is done in this aspect it can be used effectively in treating many conditions.

According to WHO more than 320 million people suffer from depression worldwide. This burden is more common among South East Asians mainly China and India. Depressive disorders are one of the major health issue faced worldwide.

Depressive disorders are characterized by sadness, loss of interest or pleasure, feelings of guilt or low self-worth, disturbed sleep or appetite, feelings of tiredness, and poor concentration. Depression can decrease the quality of life. In severe cases, depression can lead to suicide. ${ }^{7}$ Currently used drugs for the treatment of depression have numerous 
side effects. A newer drug to treat this condition might be helpful for those who are suffering from this condition. The main objective of the study is to screen aqueous extract of Psidium guajava leaves for antidepressant activity in Wistar albino rats.

\section{METHODS}

This study is preclinical animal study. The study was conducted in the Department of Pharmacology Yenepoya Medical college Mangalore. Institutional Animal Ethics Clearance (IAEC) was obtained before conducting the study (YU-IAEC bearing No.4/9.6.2016).

\section{Plant procurement}

Fresh leaves of guava (Psidium guajava Linn.) were procured from the guava plants grown in Dakshina Kannada District. It was authenticated by botanist.

\section{Preparation of guava leaf aqueous extract}

Guava leaves were washed and cleaned. It was shade dried. Later it was powdered using a blender. The dried powder was wrapped in a muslin cloth and extracted using $1000 \mathrm{ml}$ of distilled water in Soxhlet apparatus maintained at around $70^{\circ} \mathrm{C}-80^{\circ} \mathrm{C}$ for period of 3 days. ${ }^{8}$ The extract was concentrated in the Rota- vapor at $60^{\circ} \mathrm{C}$ and subsequently in the water bath for evaporation of solvent for a period of 2 days.

\section{Animals}

Healthy Wistar albino rats weighing 180-200g of either sex were included in the study. Obese and pregnant animals were excluded from the study. The animals were housed in standard cages at room temperature $28 \pm 2^{\circ} \mathrm{C}$ under the natural day and night cycles $(12 \mathrm{hr}$ dark and $12 \mathrm{hr}$ light) with free access to diet and water.

\section{Method}

Acute toxicity study of aqueous extract of Psidium guajava leaves was performed following OECD guidelines $425 .{ }^{9}$ No signs of toxicity was found at the maximum dose of $2000 \mathrm{mg} / \mathrm{kg}$ body weight. The test dose was fixed to $100 \mathrm{mg} / \mathrm{kg}$ and $200 \mathrm{mg} / \mathrm{kg}$ body weight. Standard drug used was Imipramine-10mg/kg dose per orally. ${ }^{10,11}$

Animals were divided into 4 groups consisting of six animals each. Group I is control animals which were administered with distilled water per orally. Group II is standard drug which is Imipramine $10 \mathrm{mg} / \mathrm{kg}$ per orally. Group III is test drug that is Psidium guajava leaf aqueous extract (PGAE) $100 \mathrm{mg} / \mathrm{kg}$ per orally. Group IV is test drug (PGAE) $200 \mathrm{mg} / \mathrm{kg}$ per orally. The drugs were administered for 10 days and then assessed for antidepressant activity.

\section{Assessment of antidepressant activity ${ }^{10,11}$}

\section{Forced swim test}

Cylindrical containers were used which was filled with water. Rats were allowed to swim in the container filled with water one at a time after 1 hour of administering the test drug.

It was observed for 5 minutes each and time of immobility was noted, during which the rodent does not try to escape, and they just float to keep their head above the water. The values were compared with control and standard group (Figure 1).

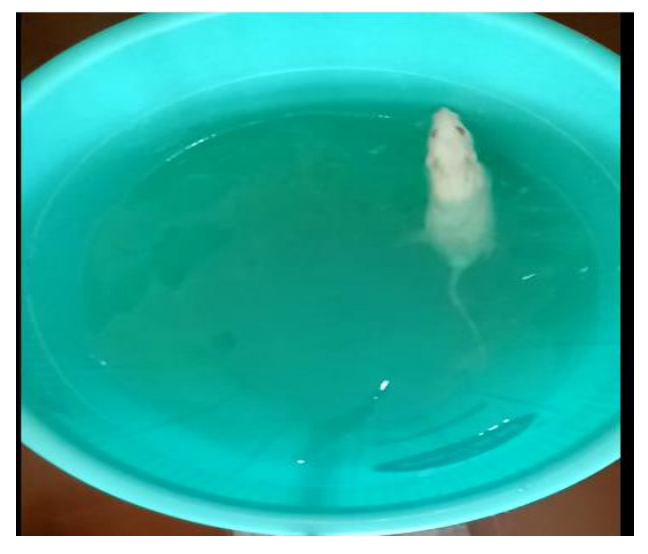

Figure 1: Forced swim test.

\section{Tail suspension test}

In this experiment rats were suspended from the edge of a table with help of adhesive tape placed approximately $1 \mathrm{~cm}$ from the tip of the tail after 1 hour of administering the drug. They were observed for 5 minutes.

Duration of immobility was noted. Rats were considered immobile when they hang freely without any movements. Assessment was done based on duration of immobility. Decrease in the duration of immobility signifies antidepressant activity (Figure 2).

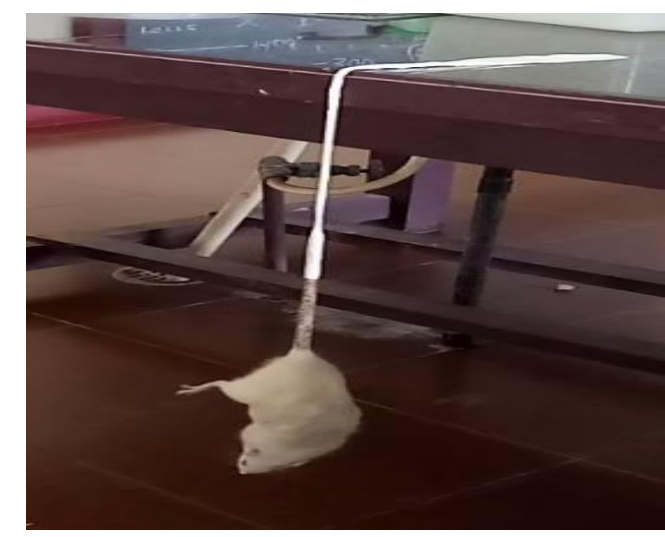

Figure 2: Tail suspension test. 


\section{RESULTS}

Data was compiled and analyzed using the statistical package, GraphPad InStat software. Results are represented as Mean \pm SEM (standard error of mean). Statistical analysis was done by one way ANOVA followed by Tukey Kramer. p value $<0.05$ was considered statistically significant. $\mathrm{P}<0.01$ were considered statistically very significant and $\mathrm{p}<0.001$ were considered very highly significant.

\section{Forced swim test}

Time of immobility was observed in seconds in all the four groups. Control group (group I) of animals showed mean period of immobility of $84.16 \pm 3.76$ seconds, standard group (group II) showed mean period of immobility of $16.16 \pm 2.99$ seconds.

Table 1: Result of forced swim test.

\begin{tabular}{|ll|}
\hline Group & $\begin{array}{l}\text { Immobile period } \\
\text { (seconds) }\end{array}$ \\
\hline Control-distilled water & $84.16 \pm 3.764$ \\
\hline Standard- Imipramine & $16.16 \pm 2.994$ \\
\hline Test drug-PGAE-100mg/kg & $36.16 \pm 2.787 *$ \\
\hline Test drug-PGAE $200 \mathrm{mg} / \mathrm{kg}$ & $23.16 \pm 3.488^{* *}$ \\
\hline
\end{tabular}

$*$ p value $<0.001$ compared to group I; **p value $<0.001$ compared to group I.

Group III and IV that is PGAE $100 \mathrm{mg} / \mathrm{kg}$ and PGAE $200 \mathrm{mg} / \mathrm{kg}$ showed mean period of immobility of $36.16 \pm 2.787$ and $23.16 \pm 3.488$ respectively. It was found that the period of immobility of both the test groups were less compared to control group of animals. p value was $<0.001$ when compared between group III and group I. Even $\mathrm{p}$ value was $<0.001$ when compared between group IV and group I. This shows that PGAE $100 \mathrm{mg} / \mathrm{kg}$ and $200 \mathrm{mg} / \mathrm{kg}$ possess very high significant antidepressant activity compared to control group. When compared between PGAE $100 \mathrm{mg} / \mathrm{kg}$ and $200 \mathrm{mg} / \mathrm{kg}$, the later had more activity (Table1).

\section{Tail suspension test}

Table 2: Result of tail suspension test.

\begin{tabular}{|ll|}
\hline Group & $\begin{array}{l}\text { Immobile period } \\
\text { (seconds) }\end{array}$ \\
\hline Control-distilled water & $94.66 \pm 4.633$ \\
\hline Standard- Imipramine & $25.5 \pm 4.506$ \\
\hline $\begin{array}{l}\text { Test drug-PGAE- } \\
100 \mathrm{mg} / \mathrm{kg}\end{array}$ & $58.16 \pm 4.30 *$ \\
\hline Test drug-PGAE $200 \mathrm{mg} / \mathrm{kg}$ & $36.16 \pm 3.97 * *$ \\
\hline
\end{tabular}

$*$ p value $<0.001$ compared to group I; **p value $<0.001$ compared to group I.

The control group (group I) of animals showed mean period of immobility of $94.66 \pm 4.633$ seconds. Group II that is standard group administered with imipramine, showed mean period of immobility of $25.5 \pm 4.506$ seconds. Both the test groups, group III and IV showed dose dependent decrease in period of immobility that is $58.16 \pm 4.30$ and $36.16 \pm 3.97$ respectively. This test showed that period of immobility was less in both the test groups (group III and IV) compared to control group. $p$ value was $<0.001$ compared to control group which signifies that it is statistically highly significant (Table 2).

\section{DISCUSSION}

Depression is a chronic psychiatric condition characterised by low mood and interest in life. There are many hypothesis which explains about depression. One among them is mono amino hypothesis which states that decreased levels of monoamines can lead to depression. One more hypothesis state that increase levels of serotonin can treat depression. Selective serotonin reuptake inhibitors act by increasing levels of serotonin. Currently used drugs in the treatment of depression acts mainly on monoaminergic system. They increase the monoamine levels and relieve depressive symptoms. ${ }^{12}$

Forced swim test and tail suspension test are the two common tests used to assess antidepressant activity of a drug in animal models. These models will create an environment where the animals cannot escape and will produce a condition in animals which is similar to depression in humans.

Forced swim test used to screen antidepressant drugs, is based on period of immobility of the rodents. Decrease period of immobility suggests that the test drug is having potent antidepressant activity. In present study, both doses of PGAE $(100 \mathrm{mg} / \mathrm{kg}$ and $200 \mathrm{mg} / \mathrm{kg}$ body weight) showed dose dependent decrease in period of immobility which signifies that the extract has got antidepressant activity.

Tail suspension test is another test to assess antidepressant activity. It differentiates antidepressant from other drugs used for anxiety and psychosis. ${ }^{10}$ PGAE $100 \mathrm{mg} / \mathrm{kg}$ and $200 \mathrm{mg} / \mathrm{kg}$ showed dose dependent decrease in period of immobility compared to control group. This suggests that PGAE has got significant antidepressant activity.

The antidepressant activity of Psidium guajava aqueous extract can be attributed to its phytochemical constituents. Literature shows that guava leaf contains flavonoids like quercetin and kaempferol. ${ }^{2}$ Previous studies show that these flavonoids like quercetin and kaempferol has got significant antidepressant activity. There are studies demonstrating that quercetin and kaempferol inhibit mono amino oxidase enzyme. ${ }^{13,14}$ So the possible mechanism of PGAE showing antidepressant effect can be due to the flavonoid components which inhibit monoamino oxidase enzyme. Inhibition of monoamino oxidase enzyme prevents oxidative deamination of biogenic amines (Adrenaline, noradrenaline, dopamine, and serotonin). Hence there is increase in levels of catecholamines and 
serotonin leading to antidepressant effect. ${ }^{12,14}$ Further studies and future research about neurotransmitter levels in this regard can confirm the exact mechanism.

\section{CONCLUSION}

The above study shows that Psidium guajava leaf aqueous extract $100 \mathrm{mg} / \mathrm{kg}$ and $200 \mathrm{mg} / \mathrm{kg}$ body weight, possess significant antidepressant activity in Wistar albino rats. PGAE 200mg/kg dose showed significant activity compared to $100 \mathrm{mg} / \mathrm{kg}$ dose. Future studies in this aspect might reveal the exact mechanism which might be responsible for the antidepressant activity.

\section{ACKNOWLEDGEMENTS}

Authors would like to thank the Department of Pharmacology, Yenepoya Medical college Mangalore for helping me to conduct this study. I would also like to thank Dr. Krishna Kumar, Professor of Botany, Mangalore University for providing authentication of the plant.

Funding: No funding sources

Conflict of interest: None declared

Ethical approval: The study was approved by the Institutional Ethics Committee

\section{REFERENCES}

1. Jaiarj P, Khoohaswan P, Wongkrajang Y, Peungvicha P, Suriyawong P, Saraya MS, et al. Anticough and antimicrobial activities of Psidium guajava Linn. leaf extract. J Ethnopharmacol. 1999 Nov 1;67(2):203-12.

2. Gutiérrez RM, Mitchell S, Solis RV. Psidium guajava: a review of its traditional uses, phytochemistry and pharmacology. J Ethnopharmacol. 2008 Apr 17;117(1):1-27.

3. Kaur G, Singh S, Goyal S, Sharma B, Siddiqui A, Mishra R. Phytochemical investigation and evaluation of anti-anxiety activity on psidium guajava linn. Leaf. World J Pharmacy Pharmaceut Sci. 2017;6(1):133241.

4. Olajide OA, Awe SO, Makinde JM. Pharmacological studies on the leaf of Psidium guajava. Fitoterapia. 1999 Feb 1;70(1):25-31.
5. Oliver-Bever B. Medicinal plants in tropical West Africa. London: Cambridge University Press, 1986:134.

6. Iwu MM, Handbook of African medicinal plants. boca raton: CRC Press Inc,1993:223-4.

7. Depression and Other Common Mental Disorders: Global Health Estimates. Geneva: World Health Organization; 2017.

Available at: http://apps.who.int/iris/bitstream/handle/10665/25461 0/WHO-MSD-MER-2017.2-eng.pdf?sequence $=1$. Accessed September 2018.

8. Maiti R, Jana D, Das UK, Ghosh D. Antidiabetic effect of aqueous extract of seed of Tamarindus indica in streptozotocin-induced diabetic rats. J Ethnopharmacol. 2004 May 1;92(1):85-91.

9. Guidelines OECD 425, Acute oral toxicity up and down procedure in OECD guidelines for the testing of chemicals, Organization for Economic Cooperation and Development. 2001;2:12-6.

10. Kalueff AV, Tuohimaa P. Experimental modeling of anxiety and depression. Acta Neurobiol Experiment. 2004 Jan 1;64(4):439-48.

11. Deng S, West BJ. Antidepressant effects of noni fruit and its active principals. Asian J Med Sci. 2011 Apr 20;3(2):79-83.

12. Tripathi KD. Essentials of medical pharmacology. 8th ed. New Delhi: Jaypee Brothers Medical Publishers; 2018:481-5.

13. Park SH, Sim YB, Han PL, Lee JK, Suh HW. Antidepressant-like Effect of Kaempferol and Quercitirin, Isolated from Opuntia ficus-indica var. saboten. Experiment Neurobiol. 2010 Jun 1;19(1):308.

14. Hosseinzadeh H, Motamedshariaty V, Hadizadeh F. Antidepressant effect of kaempferol, a constituent of saffron (Crocus sativus) petal, in mice and rats. Pharmacologyonline. 2007:2:367-70.

Cite this article as: Chaitra SR, Nayak RP, Krishna U. Evaluation of antidepressant effect of aqueous extract of Psidium guajava leaves on Wistar albino rats. Int J Basic Clin Pharmacol 2019;8:280-3. 